\title{
BMJ Open Effects of the expansion of doctors' offices adjacent to private pharmacies in Mexico: secondary data analysis of a national survey
}

\author{
Ricardo Pérez-Cuevas, ${ }^{1}$ Svetlana V Doubova, ${ }^{2}$ Veronika J Wirtz,, 4 \\ Edson Servan-Mori, ${ }^{4}$ Anahí Dreser, ${ }^{4}$ Mauricio Hernández-Ávila ${ }^{5}$
}

To cite: Pérez-Cuevas $R$, Doubova SV, Wirtz VJ, et al. Effects of the expansion of doctors' offices adjacent to private pharmacies in Mexico: secondary data analysis of a national survey. BMJ Open 2014;4:e004669. doi:10.1136/bmjopen-2013004669

- Prepublication history for this paper is available online. To view these files please visit the journal online (http://dx.doi.org/10.1136/ bmjopen-2013-004669)

Received 12 December 2013 Revised 17 April 2014 Accepted 25 April 2014

CrossMark

For numbered affiliations see end of article.

Correspondence to Dr Anahí Dreser; anahi. dreser@insp.mx

\section{ABSTRACT}

Objectives: To compare the sociodemographic characteristics, reasons for attending, perception of quality and associated out-of-pocket (OOP) expenditures of doctors' offices adjacent to private pharmacies (DAPPs) users with users of Social Security (SS), Ministry of Health (MoH), private doctor's offices independent from pharmacies and non-users.

Setting: Secondary data analysis of the 2012 National Survey of Health and Nutrition of Mexico.

Participants: The study population comprised 25852 individuals identified as having had a health problem 15 days before the survey, and a random sample of 12799 ambulatory health service users.

Outcome measures: Sociodemographic characteristics, reasons for attending healthcare services, perception of quality and associated 00P expenditures.

Results: The distribution of users was as follows: DAPPs $(9.2 \%)$, SS $(16.1 \%)$, MoH $(20.9 \%)$, private providers (15.4\%) and non-users (38.5\%); $65 \%$ of DAPP users were affiliated with a public institution (MoH 35\%, SS 30\%) and 35\% reported not having health coverage. DAPP users considered the services inexpensive, convenient and with a short waiting time, yet they received $\geq 3$ medications more often $(67.2 \%$, $95 \% \mathrm{Cl} 64.2 \%$ to $70.1 \%$ ) than users of private doctors (55.7\%, $95 \% \mathrm{Cl} 52.5 \%$ to $58.6 \%$ ) and public institutions (SS $53.8 \%, 95 \% \mathrm{Cl} 51.6 \%$ to $55.9 \%$; $\mathrm{MoH}$ $44.7 \%, 95 \% \mathrm{Cl} 42.5 \%$ to $47.0 \%)$. The probability of spending on consultations $(88 \%, 95 \% \mathrm{Cl} 86 \%$ to $89 \%$ ) and on medicines ( $97 \%, 95 \% \mathrm{Cl} 96 \%$ to $98 \%)$ was much higher for DAPP users when compared with SS $(2 \%, 95 \% \mathrm{Cl} 2 \%$ to $3 \%$ and $12 \%, 95 \% \mathrm{Cl} 11 \%$ to $14 \%$, respectively) and $\mathrm{MoH}$ users $(11 \%, 95 \% \mathrm{Cl} 9 \%$ to $12 \%$ and $32 \%, 95 \% \mathrm{Cl} 30 \%$ to $34 \%$, respectively).

Conclusions: DAPPs counteract current financial protection policies since a significant percentage of their users were affiliated with a public institution, reported higher 00P spending and higher number of medicines prescribed than users of other providers. The overprescription should prompt studies to learn about DAPPs' quality of care, which may arise from the conflict of interest implicit in the linkage of prescribing and dispensing processes.

\section{Strengths and limitations of this study}

- This study is the first that uses nationally representative household data to analyse the characteristics of users of doctors' offices adjacent to private pharmacies (DAPPs), their reasons to attend, perception of quality and associated out-of-pocket expenditures, and runs a comparative analysis with users of other healthcare services.

- This study identified that users of DAPPs: paid out-of-pocket for medical visits and medications, therefore counteracting financial protection policies, and received, on average, higher number of medicines prescribed than users of other healthcare institutions, thus signalling poorer quality of care; for DAPP medical doctors, this situation might reflect a conflict of interest given that they work for the pharmacies.

- The main limitation is that this study is a secondary data analysis; thus with the available information, it was not possible to evaluate in depth the quality of care.

\section{BACKGROUND}

In the past decade in Mexico, recognition of inequity in health, disparities in access and utilisation of health services and differences in resource allocation and health expenditures fuelled the implementation of the System for Social Protection of Health (SSPH). The SSPH aims at achieving universal healthcare coverage and financial protection for the population without Social Security (SS). However, in 2010 - 8 years after its inception-the Mexican total health expenditure accounted for only $6.2 \%$ of the gross domestic product ${ }^{1}$ from which more than half $(51.7 \%)$ is financed through out-of-pocket expenditures. Among Organisation for Economic Co-operation and Development (OECD) countries, Mexico's income inequality is the highest. ${ }^{2}$

The complexity of the Mexican healthcare system challenges the success of health 
policies because the healthcare sector comprises segmented public and private healthcare systems with little interaction. The public sector covers an estimated 78.6\% of Mexico's population ( 112 million). All formal labour market and government employees receive healthcare from the SS institutions, whereas most of the unemployed or self-employed population receives healthcare from the Ministry of Health $(\mathrm{MoH})$, which comprises each of the 32 decentralised MoH facilities in every Mexican state. The private sector provides care for the uninsured population and for up to $31 \%$ of those insured who choose to use this system for ambulatory care.

Reaching universal coverage is expected to improve access and protect the population from the financial burden of healthcare. To accomplish these endeavours, the SSPH, which is a non-contributory social health insurance programme, includes access to ambulatory and hospital healthcare in public institutions and provision of no-cost prescribed medications at the point of care. This represents actual financial protection, particularly for low-income groups. ${ }^{3} \mathrm{SSPH}$ was launched in 2002. By 2011, the programme reached 52.6 million affiliates, and the benefit package increased from 91 to 284 interventions. This package covers the treatment of $\sim 95 \%$ of the causes of visits in primary care clinics and admissions to general hospitals. ${ }^{4}$ During the same period, the proportion of patients reporting complete provision of medications at the $\mathrm{MoH}$ facilities increased from $55 \%$ to $62 \%$, whereas in the SS the increase was from $70 \%$ to $87 \%{ }^{4}$

Despite the progress, Mexican policies on access to healthcare and, in particular, to medications still stand at a crossroad and deserve careful analysis. The availability of medicines is a key determinant of access to and utilisation of health services. In Mexico, most medications are being paid for with private resources (mostly out-of-pocket) despite the important public investment in healthcare. A recent report has emphasised that for every Mx $\$ 100$ spent on medications, Mx\$79 is being paid with private resources and only Mx $\$ 21$ with public funds. ${ }^{5}$ Furthermore, in 2010, the Mexican authorities enacted a prescription-only requirement policy to enforce the regulation to sell antibiotics only with a physician's prescription. This policy, aimed at mitigating self-medication, had the unintended consequence of boosting private ambulatory healthcare in the form of doctors' offices adjacent to private pharmacies (DAPPs) ${ }^{6}$

Indeed, since a decade ago, a small number of DAPPs began to operate in some low-cost pharmacy chains, but soon after the publication of the antibiotics policy, a growing number of DAPPs have been observed nationwide. Currently, there are 10000 DAPPs in the country that provide 250000 medical visits every day. ${ }^{7}$ This emergent phenomenon questions the success of current health policies focused on universal coverage for healthcare and signals the unbalance of the supply and demand for ambulatory healthcare and medicines in the public sector. Furthermore, DAPPs challenge current regulations and norms for doctors' offices and private pharmacies.

The policies to improve access to medicines and safe prescriptions face multiple challenges such as the conflict of interest and may have unanticipated results. Until recently, in Japan and the USA, ${ }^{8}$ Korea $^{9}$ and China ${ }^{10}{ }^{11}$ among other countries, ${ }^{12}$ medical doctors and pharmacists were allowed to prescribe and dispense medicines. Such practices contributed to high medicine utilisation; for example, in China, almost $50 \%$ of the revenues of medical doctors and pharmacists came from pharmaceuticals. ${ }^{10}$ Owing to the financial incentive, more medicines were dispensed and their selection was influenced by factors other than their quality or cost-effectiveness. Recognition of this problem encouraged the introduction of reforms aimed at separating medicine prescribing and dispensing. In some countries, this strategy decreased the irrational use of medicines, ${ }^{13}$ although in other countries it provoked the practice that health providers hired onsite pharmacists. ${ }^{14}$ As the provider paid a salary to the pharmacists, the provider's incentives and irrational prescription patterns remained unchanged.

In Mexico, the expansion of DAPPs indicates that prescribing and dispensing of medicines is related instead of being separated as the international experience suggests. To better understand this situation, the objectives of this study were to compare DAPP users with users of other services in terms of their characteristics, reasons for attending specific services, perception of quality and associated out-of-pocket expenditures.

\section{METHODS}

\section{Data source}

This study is a secondary data analysis of the 2012 National Survey of Health and Nutrition (ENSANUT 2012).$^{15}$ ENSANUT is a complex survey, which is representative at the national, state and urban-rural stratum levels. It was designed to collect data on different health and nutrition conditions and the utilisation of ambulatory and hospital care services. ENSANUT 2012 was applied to 194923 individuals in 50528 households (response rate of $87 \%$ ). It was sampled through a probabilistic multistage process. The specific details on the sampling approach of ENSANUT 2012 are published elsewhere. ${ }^{15}$

To collect the information for the ENSANUT survey, previously trained interviewers carried out direct, structured face-to-face interviews with key household informants and health service users. The interviewers applied the five-questionnaire set that ENSANUT 2000 and 2006 used: household, health services use, children, adolescents and adults.

\section{Study population, variables and statistical analysis}

The present study analysed the information from the household and health services' use questionnaires of 
ENSANUT 2012. Figure 1 depicts selection of the study population.

The study population comprised: (a) individuals identified as having had a health problem within 15 days before the survey according to the household questionnaire and (b) a random sample of ambulatory health service users who answered the health services use questionnaire. ${ }^{14}$ The number of individuals who had a health problem was obtained as follows: from the total number of survey participants (194923 individuals), $26154(13.4 \%)$ reported having a health problem; after excluding the questionnaires with incomplete information, the final sample was 25852 individuals. Thus, the non-response rate was $1.2 \%$. Following the same logic, 13187 health service users were chosen; 12799 had complete information and $388(2.9 \%)$ did not.

In group ' $a$ ', we identified five categories of users of healthcare services: (1) DAPPs, (2) SS facilities, (3) $\mathrm{MoH}$ facilities, (4) offices of private doctors independent from pharmacies and (5) non-users or those who reported consulting with a friend, neighbour, family member, homeopaths or other healers. This was the dependent variable.

Data analysis was performed in two stages. In the first stage, sample 'a' served to describe the sociodemographic characteristics and identify the factors associated with the use of DAPPs in comparison with the use of other health services or no use. The analysis included the following independent variables that the literature suggests as related to the use of health services ${ }^{16-18}$ : sex (male or female), age group $(0-9,10-19,20-64$ and $\geq 65$ years) and years of schooling $(0,1-6,7-9$ and $\geq 10)$. The variable of years of schooling was obtained directly from the interview data for participants 15 years of age and older, and for individuals younger than 15 years the mean of years of schooling of the household members was used. Other analysed variables were place of residence (rural, urban or metropolitan); ethnicity of the head of household ${ }^{19}$; degree of marginalisation (very low/low, middle, high/very high) following the 2010 marginalisation index (based on access to basic infrastructure services, housing conditions, education attainment and wage earnings) at locality level ${ }^{20}$; type of medical insurance (SS, SSPH, private or none) and socioeconomic status (SES). The SES was determined classifying the population in quintiles; the information to ascertain the SES included possession of different assets, services and characteristics of the household infrastructure. ${ }^{21} 22$ The SES index was constructed using a principal components analysis with polychoric correlation matrices. Additionally, type of health problem (acute, chronic or other) and perception of severity (mild or moderate/severe) of health problem were analysed.

The factors associated with the use of a specific healthcare provider were modelled using a multinomial logistic regression ${ }^{23}$ in which the dependent variable included the five categories of health service users described before. The non-users, which represented $38.5 \%$ of the sample, were used as the reference category. In addition to the sociodemographic characteristics, the model was adjusted for the geographic region of state of residence (Northwest, Northeast, Central-North, East, West, Central-South, Southwest, Southeast). The results were reported in ORs. The hypothesis tests on the ORs estimated were performed at $1 \%, 5 \%$ and $10 \%$ confidence levels. We report various statistical goodness of fit and reliability of the estimated models (Akaike criteria (AIC), log-likelihood, LR- $\chi^{2}$ and $\mathrm{R}^{2}$-McFadden).

The second stage of the analysis focused on sample ' $b$ ' of the health service users. Participants in this part of the survey were asked about the characteristics of the healthcare received and their perceptions of the quality of care. The descriptive analysis comprised the main reasons for using specific healthcare services, the percentage of users who received information about their diagnosis, number of prescribed medicines $(0,1,2$ or 3 or more), percentage of users who received and understood the information about prescribed medicines, perception regarding the quality of care received, willingness to return to the same healthcare institution in the future and reasons for dissatisfaction with healthcare (eg, lack of improvement in health, high costs, remote services, long waiting time). We also analysed out-of-pocket expenditures for transportation from home to healthcare facilities, healthcare visits and medicines. The amount was reported in local currency (Mexican pesos). To estimate the median and IQR of waiting time and out-of-pocket expenditures by the type of healthcare provider, the quantile regression model at the population level was utilised. All statistical analyses were performed using the statistical package STATA V.12.1.

\section{RESULTS}

Table 1 summarises the characteristics of users of different healthcare services. Overall, $61.5 \%$ of participants who were reported to have had a health problem seek care with a health provider according to the following distribution: $\mathrm{MoH}(20.9 \%)$, SS (16.1\%), private providers $(15.4 \%)$ and DAPPs $(9.2 \%)$.

When the sample was stratified by insurance coverage, the results showed that a significant percentage of users with SS or SSPH insurance attended private services or DAPPs. Among DAPP users, $30 \%$ and $35 \%$ reported as having SS or SSPH coverage, respectively. Similarly, among private physician users, 39\% had SS and $26 \%$ had SSPH coverage.

DAPP users were economically better off than those who went to $\mathrm{MoH}$ facilities. In comparison to the users of other health services and non-users, DAPP users were younger ( $51 \%$ were between 0 and 19 years old), with higher educational level than $\mathrm{MoH}$ users and lower educational level than SS users. Most DAPP users lived in 


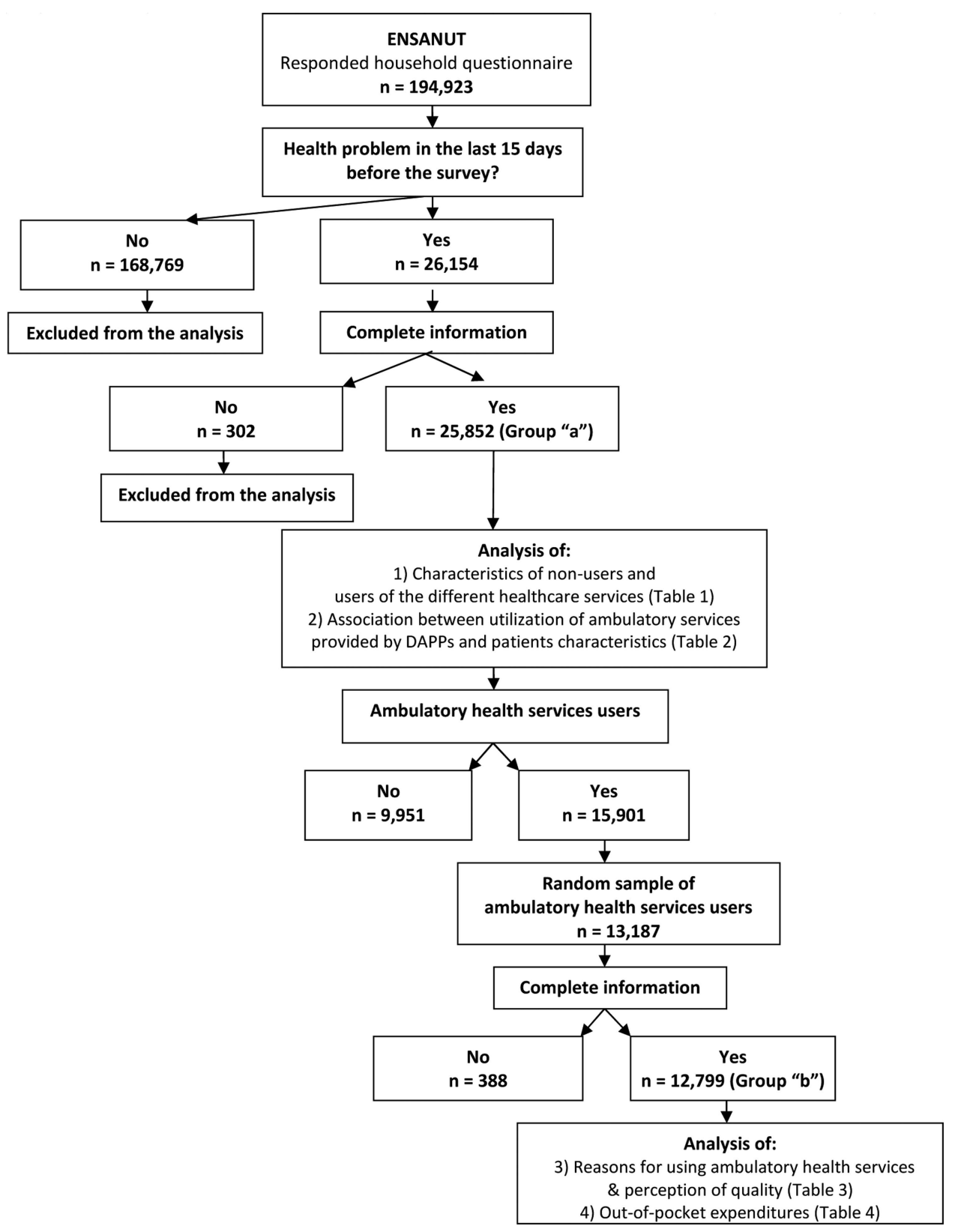

Figure 1 Selection of study population.

urban and metropolitan areas with low level of deprivation $(89 \%$ for the former and $81 \%$ for the latter), whereas only $61 \%$ of $\mathrm{MoH}$ users lived in these areas and $50 \%$ had low level of deprivation. Three per cent of DAPP users were indigenous vs $12 \%$ of indigenous users receiving care from the $\mathrm{MoH}$. DAPP users were equally distributed among the different socioeconomic levels. This is in contrast with $\mathrm{MoH}$ users who were concentrated according to the poorest quintiles, whereas SS and private service users were in the richest quintiles. Furthermore, acute health problems encouraged more frequent attendance to DAPPs $(80 \%)$ in comparison with other groups. Users sought healthcare in the institutions to which they were affiliated if they perceived that the problem was moderate to severe.
Table 2 shows the multinomial model that confirms that users of DAPPs were younger, mostly from urban and metropolitan areas and presented an acute condition. Furthermore, those with SSPH insurance were more likely to visit DAPPs than private clinics.

The reasons for using specific health services and perception of quality of care are presented in table 3 . The top three reasons for using DAPPs were that these services were inexpensive, conveniently located and had a short waiting time, whereas the main reason to use SS and $\mathrm{MoH}$ services was to have an affiliation with such institutions. Users of private doctors mentioned more often $(29 \%)$ that they knew the doctor and liked the care provided as the main reasons for attending the private doctor's office. 
Table 1 Characteristics of users and non-users of the different healthcare services, Mexico $2012^{*}$

\begin{tabular}{|c|c|c|c|c|c|c|}
\hline & DAPPs & Social Security & Ministry of Health & Private doctors & Non-users & \multirow{6}{*}{$\begin{array}{l}\text { p Value corrected by } \\
\text { survey design effect }\end{array}$} \\
\hline Observations & 2387 & 4148 & 5390 & 3976 & 9951 & \\
\hline Sample & 9.2 & 16.1 & 20.9 & 15.4 & 38.5 & \\
\hline (\%) & 1715838 & 2775195 & 2709387 & 288434 & 5967254 & \\
\hline Weighted & 10.7 & 17.3 & 16.9 & 18.0 & 37.2 & \\
\hline (\%) & \multicolumn{5}{|l|}{ Estimation $(95 \% \mathrm{Cl})$} & \\
\hline Male (vs female) & 44.7 (42.0 to 47.5 ) & 41.0 (39.0 to 43.0$)$ & 40.3 (38.6 to 42.2 ) & 45.0 (42.8 to 47.2 ) & 46.4 (45.1 to 47.7$)$ & 0.00 \\
\hline \multicolumn{7}{|l|}{ Years of age } \\
\hline $0-9$ & 35.3 (32.3 to 38.4$)$ & 18.2 (16.5 to 20.1$)$ & 29.1 (27.3 to 31.0$)$ & 30.6 (28.6 to 32.7 ) & 19.6 (18.5 to 20.8$)$ & \multirow[t]{4}{*}{0.00} \\
\hline $10-19$ & $16.5(14.5$ to 18.7$)$ & $9.2(8.1$ to 10.5$)$ & $13.7(12.5$ to 15.0$)$ & 11.9 (10.7 to 13.2$)$ & $16.4(15.5$ to 17.4$)$ & \\
\hline $20-64$ & 43.5 (40.6 to 46.5$)$ & 56.4 (54.2 to 58.7$)$ & 46.8 (45.0 to 48.6$)$ & 48.0 (45.9 to 50.1$)$ & 56.0 (54.6 to 57.4$)$ & \\
\hline$\geq 65$ & 4.8 (3.6 to 6.2 ) & 16.1 (14.4 to 17.9$)$ & $10.4(9.3$ to 11.7$)$ & 9.5 (8.4 to 10.7$)$ & $8.0(7.2$ to 8.8$)$ & \\
\hline \multicolumn{7}{|l|}{ Years of schooling } \\
\hline 0 & 3.8 (2.9 to 4.9 ) & 7.1 (6.1 to 8.3 ) & 11.1 (10.0 to 12.4$)$ & 6.5 (5.6 to 7.5$)$ & 8.1 (7.4 to 8.9 ) & \multirow[t]{4}{*}{0.00} \\
\hline $1-6$ & 46.2 (43.0 to 49.4$)$ & 36.9 (34.5 to 39.4$)$ & 54.1 (52.0 to 56.3 ) & 36.3 (34.0 to 38.7 ) & 42.7 (41.0 to 44.4$)$ & \\
\hline 7-9 & $28.8(26.1$ to 31.7$)$ & 25.6 (23.5 to 27.8 ) & 22.0 (20.2 to 23.8$)$ & 25.5 (23.7 to 27.4$)$ & 25.6 (24.3 to 26.8 ) & \\
\hline$\geq 10$ & 21.3 (18.7 to 24.1$)$ & $30.4(28.3$ to 32.5$)$ & $12.8(11.4$ to 14.4$)$ & 31.7 (29.3 to 34.2$)$ & 23.6 (22.1 to 25.2$)$ & \\
\hline Rural residence (vs urban or metropolitan) & $10.6(8.9$ to 12.5$)$ & 9.5 (8.0 to 11.2$)$ & 39.0 (36.3 to 41.7$)$ & 18.1 (16.4 to 20.0$)$ & 24.0 (22.2 to 25.8$)$ & 0.00 \\
\hline \multicolumn{7}{|l|}{ Locality deprivation level } \\
\hline Very low/low & 81.2 (78.3 to 83.8$)$ & 85.8 (83.8 to 87.7$)$ & $50.2(47.0$ to 53.4$)$ & 72.8 (70.2 to 75.3$)$ & $65.1(62.5$ to 67.6$)$ & \multirow[t]{3}{*}{0.00} \\
\hline Middle & 9.7 (7.7 to 12.1$)$ & $8.0(6.4$ to 9.8$)$ & $13.8(11.8$ to 16.2$)$ & $11.4(9.5$ to 13.8$)$ & 11.7 (9.8 to 13.9$)$ & \\
\hline High/very high & 9.1 (7.3 to 11.3$)$ & $6.2(5.0$ to 7.7$)$ & 36.0 (32.8 to 39.3 ) & 15.7 (13.8 to 18.0$)$ & 23.3 (21.0 to 25.7 ) & \\
\hline Ethnicity: Indigenous & 2.9 (2.2 to 3.9$)$ & 3.5 (2.7 to 4.6$)$ & $11.9(10.0$ to 14.1$)$ & $6.2(4.9$ to 7.9$)$ & 8.8 (7.4 to 10.3$)$ & 0.00 \\
\hline \multicolumn{7}{|l|}{ Quintile of socioeconomic status } \\
\hline 1 st & $8.3(6.5$ to 10.5$)$ & 4.1 (3.3 to 5.1$)$ & 24.5 (22.4 to 26.9$)$ & $8.1(7.0$ to 9.4$)$ & 16.7 (15.3 to 18.2$)$ & \multirow[t]{5}{*}{0.00} \\
\hline 2nd & $18.5(15.9$ to 21.5$)$ & 10.9 (9.6 to 12.3$)$ & 26.2 (24.3 to 28.2$)$ & $11.8(10.4$ to 13.4$)$ & $21.0(19.4$ to 22.6$)$ & \\
\hline 3rd & 22.4 (19.4 to 25.7$)$ & 19.3 (17.6 to 21.2$)$ & 20.1 (18.3 to 22.0$)$ & $15.7(14.1$ to 17.4$)$ & 20.3 (18.9 to 21.8$)$ & \\
\hline 4th & 26.3 (22.9 to 30.1$)$ & 25.6 (23.4 to 27.9 ) & $16.8(15.0$ to 18.7$)$ & 24.7 (22.3 to 27.1$)$ & 19.4 (17.9 to 21.1$)$ & \\
\hline 5 th & 24.5 (21.1 to 28.2$)$ & 40.1 (37.3 to 42.8 ) & $12.5(10.7$ to 14.5$)$ & 39.8 (37.0 to 42.7 ) & 22.5 (20.7 to 24.5$)$ & \\
\hline \multicolumn{7}{|l|}{$\mathrm{Ml}$} \\
\hline Social Security & 29.5 (26.6 to 32.7 ) & 94.3 (93.2 to 95.3$)$ & 6.8 (5.7 to 8.1$)$ & 39.1 (36.6 to 41.8 ) & 31.5 (29.7 to 33.3) & \multirow[t]{4}{*}{0.00} \\
\hline SSPH & 35.4 (32.1 to 38.8$)$ & 3.0 (2.3 to 3.8$)$ & 81.1 (79.3 to 82.9$)$ & 25.6 (23.6 to 27.8$)$ & 41.4 (39.6 to 43.1$)$ & \\
\hline Private insurance & 0.0 (0.0 to 0.2$)$ & 0.1 (0.0 to 0.3$)$ & $0.0(0.0$ to 1.7$)$ & $1.0(2.9$ to 0.3$)$ & 0.1 (0.5 to 0.0$)$ & \\
\hline No Ml & 35.1 (31.6 to 38.7 ) & 2.6 (2.0 to 3.4$)$ & 12.1 (10.7 to 13.6$)$ & 33.5 (31.0 to 36.1$)$ & 26.9 (25.6 to 28.3$)$ & \\
\hline \multicolumn{7}{|l|}{ Type of health problem } \\
\hline Acute health problems & 80.4 (77.7 to 83.0$)$ & 58.5 (56.3 to 60.6$)$ & 65.7 (63.7 to 67.7$)$ & 71.0 (68.9 to 73.1$)$ & 81.0 (79.7 to 82.3$)$ & \multirow[t]{3}{*}{0.00} \\
\hline Chronic health problems & 14.1 (12.0 to 16.5$)$ & 29.8 (27.7 to 32.0$)$ & 24.3 (22.5 to 26.1$)$ & 20.1 (18.4 to 22.0 ) & $10.2(9.4$ to 11.1$)$ & \\
\hline Other health problems & 5.5 (4.3 to 7.0$)$ & $11.8(10.4$ to 13.3$)$ & $10.0(8.9$ to 11.3$)$ & $8.9(7.8$ to 10.1$)$ & $8.8(8.0$ to 9.6$)$ & \\
\hline \multicolumn{7}{|l|}{ Perception of severity of health problem } \\
\hline Mild & 44.2 (41.1 to 47.4$)$ & 37.1 (34.9 to 39.4 ) & 40.4 (38.3 to 42.5 ) & 36.2 (34.0 to 38.5 ) & 63.6 (61.9 to 65.2$)$ & \multirow[t]{2}{*}{0.00} \\
\hline Moderate/severe & 55.8 (52.6 to 58.9$)$ & $62.9(60.6$ to 65.1$)$ & 59.6 (57.5 to 61.7$)$ & $63.8(61.5$ to 66.0$)$ & 36.4 (34.8 to 38.1$)$ & \\
\hline
\end{tabular}

Difference estimates performed considering the effect of the survey design.

${ }^{*}$ The variable of years of schooling was obtained directly from the interview data for participants 15 years of age and older, and for individuals younger than 15 years the mean of years of schooling of the household members was used.

DAPPs, doctors' offices adjacent to private pharmacies; MI, medical insurance; SSPH, System for Social Protection of Health. 
Regarding the average number of medicines per encounter, DAPP users received $\geq 3$ medicines more often $(67 \%)$ than users of private doctors $(56 \%)$ and public institutions (SS 54\%; MoH 45\%). A higher percentage of DAPP and private practice users received information about the diagnosis and prescribed medicines than those of public institutions. DAPP users also had better perception of the quality of healthcare (good/very good quality: DAPPs $89 \%$, private doctor 93\%) than other users (SS 78\%; $\mathrm{MoH} 83 \%$ ) and would return to the same healthcare provider. The main reason for not returning to DAPPs was lack of health improvement. For the SS and $\mathrm{MoH}$, the reasons for not returning were long waiting time, inconsiderate healthcare providers and incomplete provision of prescribed medicines.

Table 4 shows out-of-pocket expenditures for attending ambulatory care. DAPP and $\mathrm{MoH}$ users were less likely to pay for transportation ( $41 \%$ and $39 \%$ ) than SS and private doctors' users (58\% and $51 \%)$. Also, DAPP users spent less on transportation $(\mathrm{Mx} \$ 25)$ when compared with other users. The probability of spending on consultations $(88 \%$ and $87 \%)$ and on medicines $(97 \%$ and $89 \%$ ) was much higher for DAPPs and private clinic users when compared with other users; the lowest probability was for users affiliated with the SS $(2 \%$ and $12 \%$, respectively). DAPP users spent less on consultation and medicines (average cost of consultation was Mx $\$ 30$; average cost of medicines was $\mathrm{Mx} \$ 200)$ than private doctor users (consultation Mx $\$ 200$, medicines Mx $\$ 350$ ).

\section{DISCUSSION}

The main results show that DAPPs resulted in being an important key player in the healthcare sector. The positive effect is the wide acceptance of the public to attend these services because it facilitates access to ambulatory care. However, DAPPs pose a series of challenges to reach the objectives of the current health policies: (1) users pay out-of-pocket for medical visits and medications, counteracting financial protection policies; (2) the high rate of prescribed medications raises alarm about the potential flaws in the quality of care in these facilities, undermining the efforts to improve quality of care; (3) represents a conflict of interest for healthcare providers given that the medical doctors work for the pharmacies, jeopardising financial protection and quality of care.

The public has demonstrated a favourable response to attending DAPP facilities despite the fact that according to the authorities, almost $80 \%$ of the population is affiliated with a public medical insurance. ${ }^{24}$ This is congruent with the finding in our study that $25 \%$ did not have medical insurance, and this proportion was higher among DAPP users.

The fact that two-thirds of DAPP users have medical insurance can have different interpretations. The growing number of DAPPs in a short period indicates the magnitude of the challenge faced by the public healthcare sector to fulfil the demand in urban and metropolitan areas. DAPP users were willing to pay because these services were apparently inexpensive, conveniently located and with immediate access; also, by attending DAPPs, users avoided long waiting times, inconsiderate healthcare providers and the incomplete provision of prescribed medicines with the public healthcare sector.

DAPPs promote inequity and out-of-pocket expenditures because their users pay for the medications and often for the visit. This undermines the potential gains of the public policy of financial protection. Between 2003 and 2010, the public health spending aimed at people without SS protection increased $81 \%$, whereas the percentage of total health expenditures from out-of-pocket expenditures decreased by $3 \%$, from $52 \%$ to $49 \%$. This means that for every percentage point increase in public spending for persons without SS, there was a reduction of $0.04 \%$ in out-of-pocket spending. ${ }^{25}$ This suggests that despite the increase in public resources for persons without SS, this has not yet reduced out-of-pocket expenditures, which is one of the main objectives of the financial reform. Our data show that the probability of spending on medicine was higher for DAPP users than for users of other providers. Although the amount they spent is not as large as the out-of-pocket spending of users of private physicians, for those affiliated with a public institution it means additional financial burden. This could be a wake-up call to put into practice innovative and efficient patientcentered health service models focused on providing financial protection.

The presence of DAPPs in the health sector sends the signal that the Mexican regulation has a double standard for private doctors. Current regulations of the $\mathrm{MoH}$ for private pharmacies literally forbid their "direct communication, through windows, doors or aisles, with other businesses, such as doctor's offices (...). ${ }^{26}$ The rapid expansion of DAPPs shows that this regulation is either imprecise or subject to interpretations, or there is weakness of the health authority to enforce it. This situation could be interpreted as an unspoken public policy of laissez-faire to deal with the dilemma of favouring access to healthcare versus reinforcing the observance of the regulations.

Despite the fact that ENSANUT 2012 did not gather in-depth quality of care information, the results show that DAPP users were prescribed an excessive number of medicines. Almost two-thirds of users received, on average, three or more medications, despite the fact that most were young and sought ambulatory care for acute health problems, mainly mild acute respiratory illnesses (ARI). Globally, most incidences of inappropriate use of antibiotics occur in ARI. Given the large number of medicines prescribed in DAPP consultations, it is likely that this may be derived from overprescription of antibiotics. This requires in-depth analyses.

DAPPs represent a conflict of interest because the pharmacies - or related third parties - hire the medical 
Table 2 Multinomial model of the association between utilisation of services provided by DAPPs and patient characteristics, Mexico 2012

\begin{tabular}{|c|c|c|c|c|}
\hline & \multicolumn{4}{|c|}{$\begin{array}{l}\text { Reference category: non-users } \\
\text { ORs }(95 \% \mathrm{Cl}) \text { reported }\end{array}$} \\
\hline & DAPPs & Social Security & Ministry of Health & Private doctors \\
\hline \multicolumn{5}{|l|}{ Sex (Ref: female) } \\
\hline Male & $\begin{array}{l}0.863^{* *} \\
(0.786 \text { to } 0.947)\end{array}$ & $\begin{array}{l}0.872^{\star *} \\
(0.798 \text { to } 0.952)\end{array}$ & $\begin{array}{l}0.798^{\star *} \\
(0.742 \text { to } 0.859)\end{array}$ & $\begin{array}{l}0.920^{*} \\
(0.850 \text { to } 0.996)\end{array}$ \\
\hline \multicolumn{5}{|c|}{ Years of age (Ref: $\geq 65$ ) } \\
\hline$\leq 9$ & $\begin{array}{l}3.739^{\star \star} \\
(2.986 \text { to } 4.683)\end{array}$ & $\begin{array}{l}1.320^{\star *} \\
(1.114 \text { to } 1.562)\end{array}$ & $\begin{array}{l}2.061^{\star *} \\
(1.771 \text { to } 2.398)\end{array}$ & $\begin{array}{l}2.264^{\star \star} \\
(1.932 \text { to } 2.654)\end{array}$ \\
\hline $10-19$ & $\begin{array}{l}1.761^{\star *} \\
(1.388 \text { to } 2.235)\end{array}$ & $\begin{array}{l}0.623^{\star *} \\
(0.514 \text { to } 0.754)\end{array}$ & $\begin{array}{l}1.104 \\
(0.939 \text { to } 1.298)\end{array}$ & $\begin{array}{l}0.676^{\star *} \\
(0.566 \text { to } 0.808)\end{array}$ \\
\hline $20-64$ & $\begin{array}{l}1.249^{\star} \\
(1.008 \text { to } 1.547)\end{array}$ & $\begin{array}{l}0.769^{\star \star} \\
(0.665 \text { to } 0.890)\end{array}$ & $\begin{array}{l}0.880^{\star \star \star} \\
(0.770 \text { to } 1.006)\end{array}$ & $\begin{array}{l}0.653^{\star \star} \\
(0.566 \text { to } 0.753)\end{array}$ \\
\hline \multicolumn{5}{|c|}{ Years of schooling (Ref: 0 years) } \\
\hline $1-6$ & $\begin{array}{l}1.236^{\star \star \star} \\
(0.981 \text { to } 1.558)\end{array}$ & $\begin{array}{l}1.067 \\
(0.887 \text { to } 1.282)\end{array}$ & $\begin{array}{l}1.051 \\
(0.921 \text { to } 1.200)\end{array}$ & $\begin{array}{l}0.917 \\
(0.780 \text { to } 1.078)\end{array}$ \\
\hline $7-9$ & $\begin{array}{l}1.334^{*} \\
(1.046 \text { to } 1.702)\end{array}$ & $\begin{array}{l}1.069 \\
(0.875 \text { to } 1.307)\end{array}$ & $\begin{array}{l}1.050 \\
(0.904 \text { to } 1.221)\end{array}$ & $\begin{array}{l}1.264^{\star *} \\
(1.059 \text { to } 1.509)\end{array}$ \\
\hline$\geq 10$ & $\begin{array}{l}1.309^{*} \\
(1.017 \text { to } 1.685)\end{array}$ & $\begin{array}{l}1.054 \\
(0.860 \text { to } 1.291)\end{array}$ & $\begin{array}{l}1.057 \\
(0.891 \text { to } 1.253)\end{array}$ & $\begin{array}{l}1.581^{\star \star} \\
(1.316 \text { to } 1.898)\end{array}$ \\
\hline \multicolumn{5}{|c|}{ Place of residence (Ref: urban or metropolitan) } \\
\hline Rural & $\begin{array}{l}0.637^{\star \star} \\
(0.552 \text { to } 0.736)\end{array}$ & $\begin{array}{l}0.838^{*} \\
(0.732 \text { to } 0.959)\end{array}$ & $\begin{array}{l}1.358^{\star \star} \\
(1.234 \text { to } 1.494)\end{array}$ & $\begin{array}{l}1.025 \\
(0.918 \text { to } 1.145)\end{array}$ \\
\hline \multicolumn{5}{|c|}{ Locality deprivation level (Ref: low, very low level) } \\
\hline Middle & $\begin{array}{l}0.818^{* \star} \\
(0.703 \text { to } 0.952)\end{array}$ & $\begin{array}{l}1.084 \\
(0.936 \text { to } 1.256)\end{array}$ & $\begin{array}{l}1.051 \\
(0.936 \text { to } 1.180)\end{array}$ & $\begin{array}{l}1.421^{\star *} \\
(1.254 \text { to } 1.611)\end{array}$ \\
\hline High, very high & $\begin{array}{l}0.551^{\star *} \\
(0.464 \text { to } 0.655)\end{array}$ & $\begin{array}{l}0.858^{\star \star \star} \\
(0.720 \text { to } 1.022)\end{array}$ & $\begin{array}{l}0.978 \\
(0.869 \text { to } 1.102)\end{array}$ & $\begin{array}{l}1.278^{\star *} \\
(1.116 \text { to } 1.464)\end{array}$ \\
\hline \multicolumn{5}{|c|}{ Ethnicity (Ref: non-indigenous) } \\
\hline Indigenous & $\begin{array}{l}0.647^{\star *} \\
(0.519 \text { to } 0.806)\end{array}$ & $\begin{array}{l}0.959 \\
(0.782 \text { to } 1.175)\end{array}$ & $\begin{array}{l}1.171^{\star *} \\
(1.039 \text { to } 1.319)\end{array}$ & $\begin{array}{l}1.014 \\
(0.870 \text { to } 1.182)\end{array}$ \\
\hline \multicolumn{5}{|c|}{ Quintile of socioeconomic status (Ref: 5 th) } \\
\hline $1 \mathrm{st}$ & $\begin{array}{l}0.497^{\star \star} \\
(0.406 \text { to } 0.608)\end{array}$ & $\begin{array}{l}0.669^{\star \star} \\
(0.546 \text { to } 0.818)\end{array}$ & $\begin{array}{l}1.120 \\
(0.957 \text { to } 1.311)\end{array}$ & $\begin{array}{l}0.224^{\star *} \\
(0.189 \text { to } 0.264)\end{array}$ \\
\hline 2nd & $\begin{array}{l}0.834^{*} \\
(0.712 \text { to } 0.977)\end{array}$ & $\begin{array}{l}0.886 \\
(0.764 \text { to } 1.028)\end{array}$ & $\begin{array}{l}1.176^{\star} \\
(1.016 \text { to } 1.361)\end{array}$ & $\begin{array}{l}0.345^{\star *} \\
(0.301 \text { to } 0.396)\end{array}$ \\
\hline 3rd & $\begin{array}{l}0.949 \\
(0.819 \text { to } 1.100)\end{array}$ & $\begin{array}{l}0.966 \\
(0.846 \text { to } 1.103)\end{array}$ & $\begin{array}{l}1.088 \\
(0.940 \text { to } 1.258)\end{array}$ & $\begin{array}{l}0.462^{\star *} \\
(0.408 \text { to } 0.524)\end{array}$ \\
\hline 4th & $\begin{array}{l}1.080 \\
(0.936 \text { to } 1.246)\end{array}$ & $\begin{array}{l}1.034 \\
(0.915 \text { to } 1.169)\end{array}$ & $\begin{array}{l}1.157^{\star \star \star} \\
(0.996 \text { to } 1.343)\end{array}$ & $\begin{array}{l}0.711^{\star \star} \\
(0.633 \text { to } 0.799)\end{array}$ \\
\hline \multicolumn{5}{|c|}{ Medical insurance (Ref: no insurance) } \\
\hline Social Security & $\begin{array}{l}0.676^{\star *} \\
(0.597 \text { to } 0.765)\end{array}$ & $\begin{array}{l}27.495^{\star \star} \\
(22.495 \text { to } 33.607)\end{array}$ & $\begin{array}{l}0.514^{\star *} \\
(0.440 \text { to } 0.599)\end{array}$ & $\begin{array}{l}0.871^{\star \star} \\
(0.785 \text { to } 0.966)\end{array}$ \\
\hline $\mathrm{SSPH}$ & $\begin{array}{l}0.769^{* *} \\
(0.686 \text { to } 0.862)\end{array}$ & $\begin{array}{l}0.802^{* * *} \\
(0.625 \text { to } 1.029)\end{array}$ & $\begin{array}{l}3.822^{* *} \\
(3.444 \text { to } 4.241)\end{array}$ & $\begin{array}{l}0.596^{* *} \\
(0.539 \text { to } 0.659)\end{array}$ \\
\hline \multicolumn{5}{|c|}{ Type of health problem (Ref: chronic health problems) } \\
\hline Acute & $\begin{array}{l}0.730^{\star *} \\
(0.630 \text { to } 0.847)\end{array}$ & $\begin{array}{l}0.298^{\star *} \\
(0.264 \text { to } 0.336)\end{array}$ & $\begin{array}{l}0.364^{\star *} \\
(0.327 \text { to } 0.405)\end{array}$ & $\begin{array}{l}0.425^{\star \star} \\
(0.380 \text { to } 0.476)\end{array}$ \\
\hline Other & $\begin{array}{l}0.566^{\star \star} \\
(0.451 \text { to } 0.710)\end{array}$ & $\begin{array}{l}0.502^{\star \star} \\
(0.424 \text { to } 0.595)\end{array}$ & $\begin{array}{l}0.435^{\star \star} \\
(0.376 \text { to } 0.504)\end{array}$ & $\begin{array}{l}0.530^{\star \star} \\
(0.451 \text { to } 0.623)\end{array}$ \\
\hline \multicolumn{5}{|c|}{ Perception of health problem (Ref: mild health problem) } \\
\hline Moderate/severe & $\begin{array}{l}2.336^{\star \star} \\
\text { (2.123 to } 2.571)\end{array}$ & $\begin{array}{l}2.663^{\star \star} \\
(2.430 \text { to } 2.918)\end{array}$ & $\begin{array}{l}2.192^{\star \star} \\
(2.032 \text { to } 2.364)\end{array}$ & $\begin{array}{l}3.044^{\star \star} \\
\text { (2.802 to } 3.307)\end{array}$ \\
\hline Observations & & & & 25620 \\
\hline AIC & & & & 61461 \\
\hline Log likelihood & & & & -30618 \\
\hline LR $\chi^{2}$ & & & & 15399 \\
\hline Prob $>\chi^{2}$ & & & & 0.000 \\
\hline McFadden $\mathrm{R}^{2}$ & & & & 0.201 \\
\hline
\end{tabular}

Persons with private medical insurance were excluded.

${ }^{*} p<0.05,{ }^{* *} p<0.01,{ }^{* * *} p<0.10$.

DAPPs, doctors' offices adjacent to private pharmacies; SSPH, System for Social Protection of Health.

doctors to run the pharmacy-owned examining rooms and link the processes of prescription and sale of medications. According to Brody, "conflicts of interest, whether individual or organizational, occur when one enters into arrangements that reasonably tempt one to put aside one's primary obligations (patients' safety) in favor of secondary interests, such as financial selfinterest." ${ }^{27}$ The staff of DAPPs is being paid a salary plus 
Table 3 Reasons for using ambulatory health services of different providers and perception of quality, Mexico 2012

\begin{tabular}{|c|c|c|c|c|c|}
\hline & DAPPs & Social Security & Ministry of Health & Private doctors & \multirow{6}{*}{$\begin{array}{l}\text { p Value corrected by } \\
\text { survey design effect }\end{array}$} \\
\hline Observations & 1778 & 3840 & 4569 & 2612 & \\
\hline Sample & 13.89 & 30 & 35.7 & 20.41 & \\
\hline & 1504746 & 2912390 & 2602144 & 2128578 & \\
\hline Weighted & 16.45 & 31.84 & 28.45 & 23.27 & \\
\hline (\%) & \multicolumn{4}{|l|}{ Estimation (95\% Cl) } & \\
\hline \multicolumn{6}{|l|}{ Main reasons for using specific healthcare services } \\
\hline Having insurance & $1.5(0.7$ to 2.2$)$ & 88.5 (86.8 to 90.2$)$ & 59.4 (57.0 to 61.8$)$ & 2.7 (1.9 to 3.6$)$ & 0.00 \\
\hline Convenient to home & 32.5 (29.1 to 36.0$)$ & $6.3(5.1$ to 7.4$)$ & 25.2 (23.3 to 27.2$)$ & 16.6 (14.4 to 18.8$)$ & 0.06 \\
\hline Inexpensive & 33.6 (30.0 to 37.2 ) & $10.2(8.6$ to 11.9$)$ & 22.1 (20.2 to 24.0$)$ & 4.7 (3.7 to 5.8$)$ & 0.00 \\
\hline Familiar with the doctor & 8.1 (5.5 to 10.7$)$ & $2.1(1.4$ to 2.7$)$ & $2.7(1.8$ to 3.6$)$ & $29.1(26.2$ to 31.9$)$ & 0.00 \\
\hline User likes care provided & $16.0(12.9$ to 19.1$)$ & $6.0(5.0$ to 7.1$)$ & $8.2(7.1$ to 9.4$)$ & $28.2(25.7$ to 30.8$)$ & 0.00 \\
\hline Short waiting time & 26.5 (23.5 to 29.6$)$ & $2.3(1.6$ to 3.0$)$ & $2.8(2.1$ to 3.4$)$ & 22.1 (19.7 to 24.5$)$ & 0.68 \\
\hline Other & $18.7(16.0$ to 21.4$)$ & 4.8 (3.7 to 5.9$)$ & $10.2(8.7$ to 11.8$)$ & 24.2 (21.6 to 26.7$)$ & 0.00 \\
\hline \multicolumn{6}{|l|}{ Quality of healthcare } \\
\hline \multicolumn{6}{|l|}{ Number of prescribed medicines } \\
\hline 0 & $1.6(0.9$ to 2.8$)$ & $10.3(9.0$ to 11.8$)$ & $11.1(9.8$ to 12.5$)$ & $5.4(4.2$ to 6.8$)$ & 0.00 \\
\hline 1 & $8.3(6.7$ to 10.3$)$ & 10.7 (9.4 to 12.3$)$ & $12.0(10.8$ to 13.3$)$ & 9.9 (8.3 to 11.6$)$ & \\
\hline 2 & 22.9 (20.3 to 25.7$)$ & $25.2(23.2$ to 27.3$)$ & $32.2(30.2$ to 34.3$)$ & 29.1 (26.7 to 31.6$)$ & \\
\hline$\geq 3$ & $67.2(64.2$ to 70.1$)$ & $53.8(51.6$ to 55.9$)$ & 44.7 (42.5 to 47.0$)$ & 55.7 (52.8 to 58.6$)$ & \\
\hline Percentage of users who received information about their diagnosis & 90.3 (87.8 to 92.3$)$ & $84.3(82.5$ to 85.9$)$ & 84.5 (82.9 to 85.9$)$ & 92.7 (90.9 to 94.1$)$ & 0.00 \\
\hline Percentage of users who received information about prescribed medications & $92.3(90.0$ to 94.0$)$ & $85.5(83.8$ to 87.0$)$ & 86.8 (85.3 to 88.2$)$ & 93.7 (92.1 to 95.0$)$ & 0.00 \\
\hline \multicolumn{6}{|l|}{ Perception about the quality of healthcare services } \\
\hline Good/very good & 88.8 (86.4 to 90.8$)$ & 77.7 (75.5 to 79.7$)$ & 83.1 (81.4 to 84.7$)$ & $93.2(91.5$ to 94.5$)$ & 0.00 \\
\hline Regular & $10.2(8.2$ to 12.5$)$ & 16.7 (14.9 to 18.6$)$ & $13.4(12.0$ to 14.9$)$ & 5.7 (4.6 to 7.1$)$ & \\
\hline Bad/very bad & $1.1(0.6$ to 1.9$)$ & $5.7(4.6$ to 7.0$)$ & 3.5 (2.8 to 4.5$)$ & $1.1(0.5$ to 2.4$)$ & \\
\hline Users who will return to the same place for healthcare & 90.1 (87.3 to 92.4$)$ & 81.8 (79.8 to 83.7$)$ & 87.7 (86.1 to 89.1$)$ & 93.4 (91.8 to 94.7$)$ & 0.00 \\
\hline \multicolumn{6}{|l|}{ Reasons for not returning } \\
\hline Inconsiderate healthcare providers & 4.7 (2.3 to 9.7$)$ & $32.0(27.1$ to 37.3$)$ & 25.4 (20.0 to 31.7 ) & $9.1(3.9$ to 19.8$)$ & 0.00 \\
\hline Disagree with the diagnosis or treatment & $16.4(10.4$ to 25.0$)$ & $18.9(14.6$ to 24.1$)$ & $15.7(12.1$ to 20.1$)$ & 23.7 (14.6 to 36.1$)$ & 0.44 \\
\hline Lack of health improvement & 27.9 (17.1 to 41.9$)$ & 18.7 (14.6 to 23.8$)$ & 16.9 (12.6 to 22.3$)$ & $32.0(21.5$ to 44.6$)$ & 0.03 \\
\hline High cost of healthcare services & $9.8(4.4$ to 20.5$)$ & $0.5(0.1$ to 1.6$)$ & $1.4(0.7$ to 2.6$)$ & 19.7 (11.3 to 32.2$)$ & 0.00 \\
\hline Failure to provide or incomplete provision of prescribed medications & $3.3(1.2$ to 8.6$)$ & 20.6 (16.1 to 25.9$)$ & 20.8 (16.0 to 26.5$)$ & $0.2(0.0$ to 1.3$)$ & 0.00 \\
\hline Failure to provide information about the health problem and treatment & $11.4(5.9$ to 21.1$)$ & $14.0(10.8$ to 18.0$)$ & $8.6(5.1$ to 14.1$)$ & $4.0(1.9$ to 8.1$)$ & 0.04 \\
\hline Long waiting time & $2.4(0.8$ to 7.1$)$ & 40.5 (34.6 to 46.7$)$ & $31.7(25.9$ to 38.1$)$ & $2.2(0.8$ to 6.2$)$ & 0.00 \\
\hline Other reasons & $5.3(2.6$ to 10.6$)$ & $11.1(7.9$ to 15.3$)$ & $8.4(5.8$ to 12.2$)$ & $2.3(0.9$ to 6.0$)$ & 0.01 \\
\hline Waiting time (in minutes) median of (IQR) $\dagger$ & $10.0(5.0-25.0)$ & $30.0(15.0$ to 90.0$)$ & $60.0(15.0$ to 120$)$ & $10.0(5.0$ to 30.0$)$ & 0.00 \\
\hline
\end{tabular}




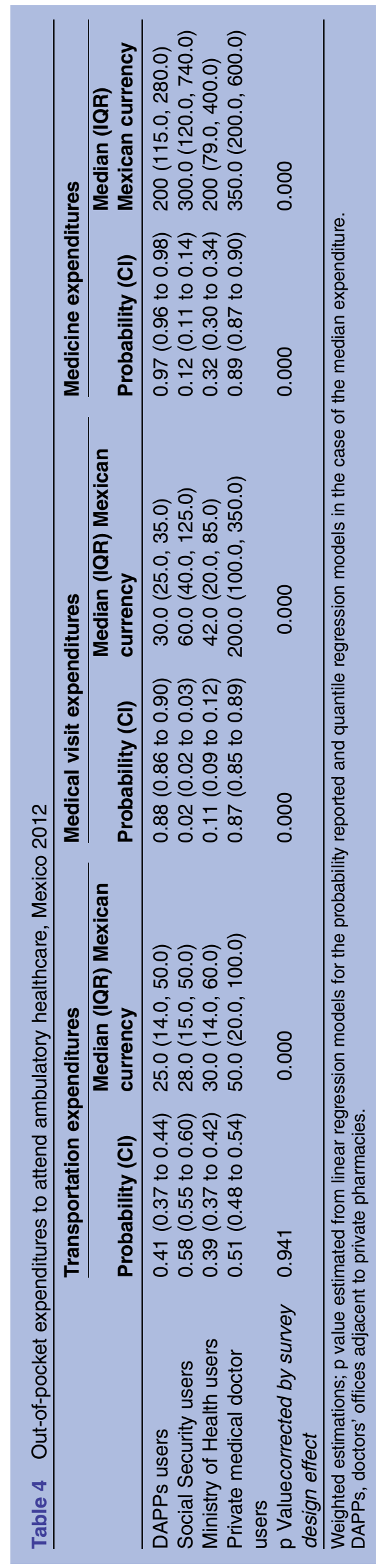

commissions derived from the prescriptions. ${ }^{28}$ This may encourage unjustified prescribing. This assumption is supported by studies from other countries where the merger of medicine prescribing and dispensing ${ }^{14} 29$ or exposure to information from pharmaceutical companies $^{30}$ affected prescription choices, prompting physicians to not necessarily act in the best interest of patients, resulting in higher prescribing frequency, higher costs and lower prescribing quality. The high number of prescribed medications indicates that medical doctors working for DAPPs may have financial incentives to prescribe certain products. The problem of overprescribing results in polypharmacy, increased out-of-pocket expenditures, increased risk of adverse medication reactions and, in the case of antibiotics, resistance. This complex situation jeopardises the objectives of the policy to sell antibiotics only with a physician's prescription.

The growing presence of DAPPs contributes to the healthcare market failure in the Mexican context. The main health policies are focused on promoting a supplierinduced demand of public health sector services. Although, the quantity of ambulatory healthcare (medical visits and medications) demanded does not equate to the supply by the public health sector. A contributing factor is the asymmetry of information between consumers and providers, which is a feature of health markets and recognised as a cause of market failure. ${ }^{31}$ Patients are usually poorly informed consumers who fail to recognise high-quality service; for example, in the present study, the interviewees attended DAPPs because it seemed to be convenient, rather than for the high quality of care offered. Availability of information about healthcare effectiveness and quality of the services is necessary for rational decision-making. It is advisable to collect data and provide to the consumers this type of information in order to enable them to make an informed choice to meet their own individual needs.

Apparently, the public sector has an unrecognised conflict between reinforcing the regulation, promoting highquality care and proper use of medications versus allowing the growing supply of this type of ambulatory care providers to absorb the spillover of the demand for consultations and medicines, regardless of the quality and cost. Little attention is being paid to developing policies aimed at regulating and taking advantage of the role of the private market to enhance competition and improve the quality of healthcare. The findings support the assumption that it is necessary to strengthen the stewardship of the $\mathrm{MoH}$ in the private sector, along with the urgent need to consolidate a national pharmaceutical policy.

The study has several limitations. It is a secondary data analysis of a cross-sectional study; thus, no longitudinal data are available to ascertain the changes of DAPP services over time. Also, the available information did not allow in-depth evaluation of the quality of prescriptions. The information was gathered through interviews during home visits; therefore, the quality of the data depends on user recall. To mitigate this potential bias, the questions only addressed the prior 15-day period. Further and 
detailed information about the contracts and remunerations of DAPP physicians is necessary in order to better evaluate the magnitude of the conflict of interest.

\section{CONCLUSION}

DAPPs have become an important player in Mexican healthcare, but they are an 'elephant in the room'. This metaphor indicates an obvious truth that is either being ignored, or goes on unaddressed. As was mentioned earlier, DAPPs have been functioning for more than a decade; their numbers reach 10000 , providing 250000 medical visits every day. However, their functioning and regulation have been unaddressed by health policies. It was very recently (late 2013) that COFEPRIS (Spanish acronym for the Federal Commission for Protection against Sanitary Risks) issued 'Guidelines for good practices' for pharmacies with doctor's offices. These guidelines compile a list of current regulations for pharmacies, on the one hand, and for ambulatory health services, on the other, but do not address the central issues of preventing conflict of interest, or assessing quality of care. The findings of this study support the notion that DAPPs counteract current financial protection policies since a significant percentage of users were affiliated with a public institution and reported higher out-of-pocket spending and higher number of medicines prescribed than users of other providers. Additionally, these results should prompt studies to learn more about the quality of care of DAPPs, which may arise from the conflict of interest implicit in the linkage of prescribing and dispensing processes. Addressing these aspects through rigorous studies can provide evidence pertinent to improve the current pharmaceutical policies in Mexico.

\author{
Author affiliations \\ ${ }^{1}$ Division of Social Protection and Health, Inter-American Development Bank, \\ Mexico, Mexico \\ ${ }^{2}$ Epidemiology and Health Services Research Unit, CMN Siglo XXI, Mexican \\ Institute of Social Security, Mexico, Mexico \\ ${ }^{3}$ Center for Global Health and Development (CGHD), Boston University, \\ Boston, Massachusetts, USA \\ ${ }^{4}$ Centre for Health Systems Research, National Institute of Public Health, \\ Cuernavaca, Mexico \\ ${ }^{5}$ National Institute of Public Health, Cuernavaca, Mexico
}

Contributors RP-C, MH-A, SVD, VJW and AD conceptualised the study. SVD and $A D$ conducted the literature review. RP-C, SVD, ES-M, VJW and MH-A designed the study. ES-M analysed the data. RP-C, SVD, VJW, ES-M, AD and $\mathrm{MH}-\mathrm{A}$ interpreted the data, wrote the manuscript and approved the final draft.

Funding This research received no specific grant from any funding agency in the public, commercial or not-for-profit sectors.

Competing interests None.

Ethics approval This study is a secondary data analysis of the ENSANUT 2012. The data for the analysis were requested and obtained from the surveys public repository hosted at the National Institute of Public Health webpage at: http://ensanut.insp.mX/. This repository has the data already de-identified; thus it is not possible to trace any of the data to the actual individual. In accordance to the Internal Regulation of the Research Ethics Committee of the National Institute of Public Health, this secondary analysis was considered exempt of approval.

Provenance and peer review Not commissioned; externally peer reviewed.
Data sharing statement No additional data are available.

Open Access This is an Open Access article distributed in accordance with the Creative Commons Attribution Non Commercial (CC BY-NC 3.0) license, which permits others to distribute, remix, adapt, build upon this work noncommercially, and license their derivative works on different terms, provided the original work is properly cited and the use is non-commercial. See: http:// creativecommons.org/licenses/by-nc/3.0/

\section{REFERENCES}

1. Organisation for Economic Co-operation and Development. OECD Health Data 2013: how does Mexico compare. Organisation for Economic Co-operation and Development, 2013. http://www.oecd. org/mexico/Briefing-Note-MEXICO-2013.pdf

2. Organisation for Economic Co-operation and Development. An overview of growing income inequalities in OECD countries: main findings. Organisation for Economic Co-operation and Development, 2011. http://www.oecd.org/els/soc/49499779.pdf

3. Wirtz VJ, Reich MR, Leyva-Flores R, et al. Medicines in Mexico, 1990-2004: systematic review of research on access and use. Salud Publica Mex 2008;50:S470-9.

4. Knaul FM, González-Pier E, Gómez-Dantés O, et al. The quest for universal health coverage: achieving social protection for all in Mexico. Lancet 2012;380:1259-79.

5. Fundación Mexicana para la Salud: Trabajando por la salud de la población. Propuestas de política para el sector farmacéutico. Versión para el diálogo. FUNSALUD, A. C., 2011. http://www. funsalud.org.mx/eventos_2011/trabajando\%20por\%20la\%20salud/ Doc\%20PolPublSFarm\%20vFDigital\%20060511.pdf

6. Dreser A, Vázquez-Vélez E, Treviño S, et al. Regulation of antibiotic sales in Mexico: an analysis of printed media coverage and stakeholder participation. BMC Public Health 2012;12:1051. http:// www.biomedcentral.com/1471-2458/12/1051 (accessed 6 Mar 2013).

7. Federal Commission for Protection against Sanitary Risks (COFEPRIS). Strategies to regulate doctor's offices adjacent to private pharmacies. http://www.cofepris.gob.mx/Paginas/Inicio.aspx (accessed 30 Mar 2014).

8. Rodwin M, Okamoto A. Physicians' conflicts of interest in Japan and the United States: lessons for the United States. J Health Polit Policy Law 2000;25:343-75.

9. Kwon S. Pharmaceutical reform and physician strikes in Korea: separation of drug prescribing and dispensing. Soc Sci Med 2003;57:529-38.

10. Liu X, Mills A. The influence of bonus payments to doctors on hospital revenue: results of a quasi-experimental study. Appl Health Econ Health Policy 2003;2:91-8.

11. Sun Q, Santoro MA, Meng Q, et al. Pharmaceutical policy in China. Health Aff (Millwood) 2008;27:1042-50.

12. Trap B, Hansen EH, Hogerzeil H. Prescription habits of dispensing and non-dispensing doctors in Zimbabwe. Health Policy Plan 2002;17:288-95.

13. Park S, Soumerai SB, Adams AS, et al. Antibiotic use following a Korean national policy to prohibit medication dispensing by physicians. Health Policy Plan 2005;20:302-9.

14. Chou YJ, Yip WC, Lee CH, et al. Impact of separating drug prescribing and dispensing on provider behaviour: Taiwan's experience. Health Policy Plan 2003;18:316-29.

15. Romero-Martínez M, Shamah-Levy T, Franco-Núñez A, et al. National Health and Nutrition Survey 2012: design and coverage. Salud Publica Mex 2013;55:S332-40.

16. Brown C, Pagán J, Rodríguez-Oreggia E. The decision-making process of health-care utilization in Mexico. Health Policy 2005;72:81-91.

17. López-Ceballos D, Chi C. Health-care utilization in Ecuador: a multilevel analysis of socio-economic determinants and inequality issues. Health Policy Plan 2010;25:209-18.

18. Valdivia M. Public health infrastructure and equity in the utilization of outpatient health-care services in Peru. Health Policy Plan 2002;17:12-19.

19. Comisión Nacional para el Desarrollo de los Pueblos Indígenas (CDI). Los hogares y la población indígena. 2009. http://www.cdi. gob.mx/index.php?id=211\&option=com_content\&task=view (accessed 6 Mar 2013).

20. Consejo Nacional de Población (CONAPO). Índice de marginación por localidad. http:/www.conapo.gob.mx/es/CONAPO (accessed 20 Mar 2013). 
21. Kolenikov S, Angeles $\mathrm{G}$. The use of discrete data in PCA: theory, simulations, and applications to socioeconomic indices. Chapel Hill: Carolina Population Center, University of North Carolina, 2004.

22. McKenzie DJ. Measuring inequality with asset indicators. J Popul Econ 2005;2. http://siteresources.worldbank.org/DEC/Resources/ finaljpopmckenzie1.pdf (accessed 2 Feb 2013).

23. Hosmer D, Lemeshow S. Applied logistic regression. 2nd edn. Wiley Series in Probability and Statistics, 2000.

24. Ministry of Health. Health Sector Program 2013-2018. Diario Oficial de la Federación 12.12.2013. México, 2013.

25. Muñoz O, Rodríguez-Ortega E, Pérez-Cuevas R, et al. Propuesta de un Sistema Nacional de Servicios de Salud: componente de salud de una propuesta de seguridad social universal. Documento elaborado por el Centro de Estudios Económicos y Sociales en Salud (CEESES) del Hospital Infantil de México Federico Gómez (HIMFG) para el Consejo Nacional de Evaluación de la Política de Desarrollo Social (CONEVAL). México: UNAM, Seminario sobre Medicina y Salud, 2012.
26. Farmacopea de los Estados Unidos Mexicanos. Suplemento para establecimientos dedicados a la venta y suministro de medicamentos y otros insumos para la salud. México: Secretaria de Salud, 2010.

27. Brody H. Professional medical organizations and commercial conflicts of interest: ethical issues. Ann Fam Med 2010;8:354-8.

28. Leyva-Piña MA, Pichardo-Palacios S. Los médicos de las Farmacias Similares: Degradación de la profesión médica? Polis 2012:8:143-75

29. lizuka T. Experts' agency problems: evidence from the prescription drug market in Japan. Rand J Econ 2007;38:844-62.

30. Spurling GK, Mansfield PR, Montgomery BD, et al. Information from pharmaceutical companies and the quality, quantity, and cost of physicians' prescribing: a systematic review. PLOS Med 2010;7: e1000352. http://www.plosmedicine.org/article/info\%3Adoi\%2F10. 1371\%2Fjournal.pmed.1000352 (accessed 15 Jan 2013).

31. Watts JJ, Segal L. Market failure, policy failure and other distortions in chronic disease markets. BMC Health Serv Res 2009;9:102. 